FILOZOFIA

Roč. 76, 2021, č. 4

DOI: https://doi.org/10.31577/filozofia.2021.76.4.5

\title{
ECO A VATTIMO - NEGATÍVNY REALIZMUS VERZUS SLABÉ MYSLENIE
}

Martin Vašek, Univerzita Konštantína Filozofa v Nitre, Filozofická fakulta, Katedra filozofie, SR

VAŠEK, M.: Eco and Vattimo - Negative Realism versus Weak Thought

FILOZOFIA, 76, 2021, No 4, pp. 293 - 306

\begin{abstract}
The paper intends to introduce main points of Eco's critique of Vattimo's philosophy. It focuses on differences in their approaches and provides a closer view of one of the philosophical discussions happening at the wake of the new millennium. We focus on understanding reality and the limits of interpretation as the two key points of Eco's consideration and criticism. In 1983, Umberto Eco participated in publishing the well-known volume "weak thought", although he later no longer considered himself part of the philosophical initiative. He represents a position of minimal or negative realism. Gianni Vattimo is a proponent of the "weak thought", where reality is not introduced as stable, natural or objective. Reality does not itself speak out but needs a spokesmen or motivated interpreters. Vattimo, therefore revives Nietzsche's thought "There are no facts, only interpretations", which he deploys further in his own way.
\end{abstract}

Keywords: Umberto Eco - Gianni Vattimo - Realism - Weak Thought - Interpretation

\section{Úvod}

Umberto Eco sa v roku 1983 podiel'al na zostavení známeho zborníka Slabé myslenie (Il pensiero debole), ktorý akoby sa stal manifestom slabého myslenia. Editormi zborníka boli Gianni Vattimo a Pier A. Rovatti. Eco však spätne objasnil, že v tom čase program slabého myslenia nebol ešte striktne vyjadrený sloganom „neexistujú fakty, iba interpretácie“, neuvedomil si, že návrat k Nietzscheho filozofii implikuje prijatie tejto idey. S ňou bol neskôr spájaný, a tým zarad’ovaný medzi takzvaných „slabých myslitel'ov“ (Eco 2012b, 578). Eco sám sa do tejto línie nezarad’oval, dištancoval sa od nej a tvrdil, že jeho pozícia bola odlišná od Vattimovej už od začiatku, teda už v roku vydania uvedenej publikácie. Bol presvedčený, že fakty sú tie „veci“, ktoré odolávajú interpretáciám. V jednom z neskorších textov uvedie: „Fakta jsou tím, co nás okamžitě upozorní, když je interpretujeme špatně, že touto cestou nikam nedojdeme. Chápu, že tato definice faktů může být pro mnohé neuspokojivá, avšak nejen filozofové, ale i vědci postupují tímto způsobem“ (Eco 2016, 253). Jeho chápanie limít, respektíve hraníc výkladu sa netýka iba prírodných objektov, ale aj textov. „Je-li hermeneutickým principem to, že neexistují fakta, ale jen 
interpretace, pak to nevylučuje, že se můžeme ptát, zda neexistují náhodou i interpretace ,špatné ““ (Eco 2011, 50).

V roku 2007 vyšla v Kanade publikácia pri príležitosti Vattimovho životného jubilea s názvom Weakening Philosophy: Essays in Honour of Gianni Vattimo, s textami popredných svetových filozofov a teoretikov. Eco prispel článkom s titulom Slabé myslenie a dejiny interpretácie, ktorý vyšiel aj v českom preklade ako posledná, teda osemnásta kapitola knihy Od stromu k labyrintu. Pôvodne išlo o Ecov príspevok prednesený na univerzite v Sofii v roku 2004. V tomto texte sa Vattimovmu mysleniu venuje najvýraznejšie.

Zámerom článku je predstavit' hlavné body Ecovej kritiky Vattima, poukázat’ na odlišnost' ich prístupu a približit' tak jednu z filozofických diskusií z prelomu milénií. Dôraz budem klást' na dva Ecom kritizované a traktované klúčové problémy, ktorými sú chápanie reality a hraníc interpretácie. V poslednej časti príspevku problematiku rozviniem a uvediem niekol'ko poznámok.

\section{Realita a jazyk podl'a Eca}

V zborníku Il pensiero debole (1983), ktorý som spomenul v úvode, v článku nazvanom Anti-Porfyrios pripisoval Eco silnému mysleniu dva ideály. Prvým je ašpirácia na myslenie, ktoré je také komplexné, že môže objasnit' a popísat totalitu sveta našej skúsenosti, alebo prirodzeného sveta. Druhým je ašpirácia konštruovat model sveta, ktorý je zjednodušený (už nie je natol'ko komplexný) a intersubjektívne kontrolovatelný; myslenie preto môže odrážat' jeho štruktúru. $\mathrm{V}$ druhom prípade na to aby mohol byt' intersubjektívne kontrolovatel'ný, má myslenie formu jazyka $J$ s jeho vlastnými pravidlami, pričom tieto pravidlá sú rovnaké ako pravidlá modelu (štruktúry) sveta, ktorý jazyk vyjadruje. Nielen experimentálna veda, ale každá axiomatická disciplína je príkladom silného myslenia (Eco 2012a, 75 - 99).

Prečo však obrat k Porfyriovi, aký zámer tým Eco sledoval? Porfyrios bol prvý, kto redukoval Aristotela do „podoby“, štruktúry či termínov stromu, pričom môžeme predpokladat', že sám Aristoteles by bol flexibilnejší v tom, ako by si predstavoval viaceré stromy, pravdepodobne navzájom komplementárne. V zásade Ecovi šlo o odlíšenie slovníkovej a encyklopedickej sémantiky. Encyklopedické sémantické myslenie nie je slabé v tom zmysle, že je neschopné vysvetlit', ako použivame jazyk, ale pretože odovzdáva, respektíve ponecháva právo signifikácie kontinuálnej determinácii kontextu a okolností. Encyklopedická sémantika neodmieta poskytovat' pravidlá pre generovanie a interpretáciu jazykových vyjadrení, ale tieto pravidlá sú kontextuálne orientované a sémantika inkorporuje pragmatiku. Encyklopédiu robí slabou fakt, že definitívne a uzatvorené reprezentácie sveta nie sú nikdy produkované. Encyklopedická reprezentácia nie je nikdy globálna, ale vždy lokálna a vytvorená v zornom 
poli determinovaného kontextu a okolností, pričom predstavuje limitovanú perspektívu semiotickej aktivity (Eco 2012a, 95).

Projekt encyklopedickej kompetencie môže byt' vyjadrený metaforou labyrintu, respektíve topologickým modelom polydimenzionálnej siete. Porfyriov strom reprezentuje v dejinách silného myslenia pokus redukovat' labyrint, ktorý je polydimenzionálny, na dvojdimenzionálnu schému. Siet' nie je strom, ale strom plus nekonečné koridory, ktoré spájajú jednotlivé výhonky či vetvy stromu. Tento typ labyrintu - siet' - nemá nevyhnutne za následok iracionálne univerzum. Pre Eca však predstavuje model, ktorý môže byt' zvolený slabým systémom myslenia par excellence. Systém myslenia labyrintu, respektíve encyklopédie, je slabý natol'ko, nakol'ko je konjekturálny ${ }^{1}$ a kontextuálny. Eco však dodáva, že je racionálny, pretože dovoluje intersubjektívnu kontrolu a nevedie ani $\mathrm{k}$ renunciácii, ani $\mathrm{k}$ solipsizmu a obsah myslenia je odôvodnený súcnom, primeraný súcnu (with being reasonable). Ide o odôvodnený prístup, pretože neašpiruje na globalitu a je slabý tým spôsobom, akým je slabý orientálny zápasník, ktorý využíva nepriatel'ovou silu, t’aží z nej, oslabuje ju a nemá striktné predeterminované pravidlá.

Eco v spomenutom zborníku z osemdesiatych rokov týmto zachoval myšlienku intersubjektívnej kontroly a ,primeranosti“ $\mathrm{k}$ súcnu v prípade nášho poznania a prístupu k svetu. V neskoršom príspevku k Vattimovmu jubileu, teda o dvadsatštyri rokov neskôr, pokračuje v tejto línii a tvrdí, že na presvedčenie „neexistujú fakty, iba interpretácie“, reagoval tvrdením, že každý fakt síce vyvoláva rôzne interpretácie, no fakty majú zvláštnu vlastnost', ktorou je ich odolnost' voči interpretáciám, ktoré nepodporujú; teda voči nesprávnym, „scestným“ výkladom, pričom fakty sú parametrami našich interpretácií (Eco 2012b, 581). Pridŕžal sa popperovského princípu, podl'a ktorého aj ked' nedokážeme rozpoznat' správnu interpretáciu, sme schopní odhalit' nesprávnu, kontextuálne nelegitímnu. Eco poukazoval na možnost' „minimálneho“ realizmu, ked' realista je ten, kto predpokladá, že veci „sú“ nejakým spôsobom, aj ked” nemusíme presne vediet' akým, a môže to pre nás zostat' navždy neznáme. Realista tohto typu sa bude usilovat' o vždy nové, upresňujúce poznanie, a bude korigovat' predchádzajúce mylné závery. $\mathrm{V}$ tejto súvislosti odkazoval na dánskeho lingvistu Hjelmsleva, ktorý nechápal dánsky výraz mening $\mathrm{v}$ zmysle významu, ale skôr smeru, podobne ako v meste jestvujú prikázané a zakázané smery jazdy. Kládol si otázky: „co nám zabraňuje domnívat se, že všechny perspektivy jsou správné, že Svět je jen produkt jazyka a že kromě toho, že je poddajný a slabý, je pouhý flatus vocis? [...] Jaké je kritérium, které nám dovoluje rozlišovat na jedné straně sen, básnickou invenci

\footnotetext{
${ }^{1}$ Lat. coniectūra-dohad, domnienka, predpoklad.
} 
či stav po použití LSD, [...] a na straně druhé přijatelná tvrzení o materiálním a historickém světě, který nás obklopuje“ (Eco 2012b, 593 - 594; Eco 2011, 51)?

$\mathrm{Na} 23$. svetovom kongrese filozofie $\mathrm{v}$ Aténach $\mathrm{v}$ roku 2013 Eco predniesol prednášku s názvom Niekol'ko poznámok $k$ novému realizmu, v ktorej realizmus chápal ako reakciu na takzvanú postmodernú filozofiu (Eco 2012c). Čerpal v nej vel’a zo svojich starších textov. Eco predpokladal, že ani ten najväčší fundamentalista spomedzi dekonštruktivistov si reálne nemyslí, že vôbec nejestvujú fakty (ako také). Je tu predsa niečo, čo interpretujeme, a ak rad interpretácií nemá finálny terminus ad quem, má prinajmenšom terminus a quo, východiskový bod, fakt. Dekonštruktivisti podla neho jednoducho predpokladajú (v línii Nietzscheho), že fakty poznáme iba prostredníctvom našich interpretácií. Poznaním interpretácií a následných interpretácií interpretácie nebudeme nikdy disponovaní k poznaniu veci ako takej. Následne sa vracia k Nietzscheho výpovedi „nejestvujú fakty, iba interpretácie“. V diele $O$ pravde a lž $i$ $v$ nie morálnom zmysle Nietzsche predsa len o určitých obmedzeniach hovorí, nazýva ich „desivé sily“, ktoré na nás nepretržite tlačia a stavajú proti sebe „vedecké“ pravdy a pravdy inej povahy. To, čo Nietzsche nazval „desivou silou“, nazýval Eco „tvrdé jadro bytia“" (hard core of Being). Nemal ním na mysli vnútornú stabilnú podstatu, ale hranice rezistencie (lines of resistence), ktoré robia niektoré naše prístupy ku skutočnosti neúspešnými a jalovými. Ako uviedol v diele Kant a vtákopysk, to že bytie kladie diskurzu určité hranice, nie je popretím hermeneutickej činnosti, ale skôr jej podmienkou. Keby sme predpokladali, že o bytí môžeme povedat' čokol'vek, stratilo by zmysel dobrodružstvo večného pýtania. „Věčné tázaní se jeví jako rozumné a lidské právě proto, že předpokládáme, že tu nějaké Meze jsou“ (Eco 2011, 53). Bytie nie je účinkom jazyka v tom zmysle, že ho jazyk l’ubovol’ne konštruuje; jazyk nekonštruuje bytie, ale nachádzame niečo už dané, hranice rezistencie.

Idea hraníc rezistencie, podl'a ktorej jestvuje niečo, čo nezávisí od našich interpretácií a spochybňuje ich, vzdoruje im, je ideou reprezentujúcou formu minimálneho alebo negatívneho realizmu, podl'a ktorého ak mi aj fakty „nehovoria“, že mám prav$\mathrm{du}$, často môžem aspoň príst' $\mathrm{k}$ záveru, že sa mýlim. Tento typ realizmu sa netýka iba nášho poznania takzvaných jednoduchých faktov, ale aj nášho výkladu textov, nielen percepcií vecí, ale aj čítania kníh.

Eco predpokladal, že jestvujú podobnosti medzi jeho ideou negatívneho realizmu a Popperovou teóriou falzifikácie a že tézy o minimálnom realizme môžu byt' preložené do termínov Peirceovej filozofie. Podrobne analyzoval základné pojmy Peirceovej filozofie - Ground, Dynamický predmet, Bezprostredný predmet. Domnieval sa, že aj ked' budeme kognitívnu schému považovat' za konštrukt, „,nelze nikdy přistoupit na to, že segmentace, jejímž je výsledkem, je naprosto libovolná, protože (jak u Kanta, tak u Peirce) tato segmentace je snahou vysvětlit něco, co je zde, snahou vysvětlit síly, 
které z vnějšku působí na náš smyslový aparát a vykazují přinejmenším jisté mantinely“ (Eco 2011, 116). Snažil sa o spojenie Hjelmslevovho štrukturalistického pohl'adu a Peirceovej kognitívno-interpretačnej semiotiky. Ich spojitost' nepokladal za synkretizmus. Kategoriálny a pozorovací (resp. štrukturálny a interpretačný) moment poznania, sa nestavajú proti sebe, ani nie sú synkreticky prepojené, ale sú komplementárne a v poznaní sa vzájomne predpokladajú (Eco 2011, 241).

Eco pripomenul, že už vo svojej knihe Medze interpretácie (1990) jeho esej o neobmedzenej semióze a hermeneutickom drifte nastol'ovala aj problém hraníc interpretácie sveta. V diele Kant a vtákopysk tvrdí, že ak prijmeme Vattimovu ideu o konci stabilných štruktúr bytia, ak bytie bude iba tým, čo sa ustavične odkladá a uniká, ak sa o bytí hovorí mnohými spôsobmi a z rôznych perspektív, je takéto bytie rozožraté či „prežrané“, schátrané, poddajné, slabé, bude iba flatus vocis. Aj ten, kto by tvrdil, že bytie je čistý chaos a je vypovedatel'né akýmkol'vek spôsobom, by musel prinajmenšom vylúčit', že nie je nepoddajným poriadkom. „Jazyk nekonstruuje bytí ex novo: ptá se po něm a nachází vždycky něco již daného (i když toto již dané neznamená již dokončené a kompletni). I kdyby bytí bylo „prožrané“, stále by tu byla jakási látka, jejíž vlákna, přerušená nespočtem děr, nadále svéhlavě odolávaji““ (Eco 2011, 56). Voči Vattimovi preto vznáša kritickú poznámku a otázku: „Kdyby Vattimo přistoupil na to, že i jeho ,slabost‘ je metaforou pro dobře vyvážené myšlení, mohl by vstoupit do mé sekty. Lze však tam, kde je vše metafora, ješš něco označit za metaforu jako takovou“ (Eco 2012b, 599)?²

\section{Realita a jazyk podl'a Vattima}

Vattimo tvrdí, že ak hovoríme o realizme, musíme hovorit’ o „zvádzaní“ či „pokušení“ realizmu, pretože tak ako pokušenie, aj problém realizmu sa znovu vracia, sužuje nás, je permanentný. Je presvedčený, že realisti sú vinní paradoxne príliš malým realizmom. Nevedia uchopit' a „adekvátne“ opísat' skúsenost', z ktorej vychádzajú, vlastný „základ“. A práve táto skúsenost’ je tým, čo vskutku konštituovalo „realitu“ mnohých filozofií od Nietzscheho cez Heideggera až k postmodernizmu, ale aj k rôznym školám psychoanalýzy či k postanalytickej filozofii. S odkazom na Nietzscheho a Heideggera chce Vattimo zdôraznit', že iba bytie, ktoré sa „,deje“, legitimizuje ideu pravdy ako interpretáciu, a nie ako korešpondenciu. Ak vezmeme vážne vznik vyššie uvedených smerov a ich akcentovanie interpretácie, jej prenikanie do postmodernej kultúry, ak budeme vzt'ahovat' interpretačný postoj aj na samu interpretáciu a nebudeme ju chápat' ako novú relativistickú podobu metafyziky, znamená to spoznat' samých seba

\footnotetext{
${ }^{2} \mathrm{~K}$ tematike metafory odkazujem na text Metafora ako kritérium posunov v chápaní jazyka a komunikácie (Štúr 2018).
} 
ako tých, ktorí sú „odniekial““, sú podmienení a dejinní. Vychádzajúc z tejto perspektívy, ktokol'vek obraňuje práva realizmu alebo metafyziky ako vedomej a praktickej reflexie objektívnej pravdy bytia, je v rámci rozhovoru ako „interpret“ a ako ktorýkol'vek iný účastník tohto rozhovoru. Vattimo preto uprednostňuje vol'bu hermeneutiky pred realizmom, alebo metafyzickým relativizmom či metafyzikou vôbec. Nazdáva sa, že metafyzikova vôl'a k pravde začína s akceptovaním predstavy o objektívnej reflexii stavu vecí, pričom táto reflexia môže byt' vhodná ako finálna hodnota (obsah) pre d’alšie myslenie a konanie. Projekt, ktorého konečným zámerom je reflexia vecí tak, ako sú, založený na idei objektívnej pravdy, vyvoláva mnoho námietok a t’ažkostí. Naproti tomu je tu prístup, ktorý sa zrieka nároku zmocnit' sa základu dejinnosti (stock of historicity), a to najmä svojej vlastnej (Vattimo 2016, 72 - 74).

Vattimo vyslovuje tézu, že nihilistická ontológia hermeneutiky má dobré predpoklady na to, aby sa sama prezentovala ako koiné kultúry nášho veku. Odmietnut' hermeneutiku ako nihilistickú ontológiu sa však zdá priam nevyhnutné, pretože validita experimentálnych vied o prírode by bola podkopaná. Zdá sa totiž, že prijatím hermeneutiky s jej referenciou na dejinnost' (a tým podmienenost') foriem nášho poznania, hrozí nebezpečenstvo delegitimizácie vedy (metodologický anarchizmus) a morálky, čo ale Vattimo odmieta. Hovorit’ o prevzatí a počúvaní „správ“, „Zvestí“ a preferovat' ho pred „stretnutím“ s objektmi alebo pred registráciou impresií našej mysle neznamená ohrozovat' činnost' vedy ani naše každodenné konanie a vzt'ahy s druhými. Svet „vonku“ nie je fixovaná totalita objektov nezávislých od nášho vedomia, ale dedičstvo interpretácí. Apelácia na objektivitu vecí, na ich uchopenie tak, ako sú, je iba téza určitej osoby voči téze inej osoby; je to interpretácia motivovaná istým ,projektom“, anticipáciami, záujmami, vôl'ou. Realita nehovorí sama zo seba, ale potrebuje hovorcu či motivovaných interpretov rozhodujúcich o tom, ako zobrazit' na mape teritórium, ku ktorému mali prístup prostredníctvom mnohých starobylých „máp“ (zdedených, zachovaných). Vzdat' sa myšlienky kognitívnej schémy odzrkadlujúcej svet ako fixovanú totalitu nezávislých objektov znamená uvedomit' si a prijat' skutočnost', že sme do sveta „vhodení“, „vrhnutí“ ( geworfen) a nezačíname bez dedičstva, ktoré nás predchádza (Vattimo 2016, 76 - 78).

Pre hermeneutickú ontológiu má rozhodujúci význam Heideggerova filozofia. V knihe Budúcnost' náboženstva Vattimo píše: „Existenciální analýza Bytí a času nepředstavuje popis podstaty a struktury lidské existence; je to už v každém smyslu interpretace, to znamená naslouchání tomu a reagování na to, co jsme, když jsme a to zvnitřku. Pokud existuje nějaký rozdíl mezi ,raným‘ a ,pozdním‘ Heideggerem, [...] spočívá ve stále explicitnějším pochopení, že bytí, do nějž jsme vrženi a na něž zevnitř reagujeme, má silně dějinný charakter“ (Rorty, Vattimo 2007, 48). „Byt"“- 
s odkazom na Heideggera - znamená byt'-vo-svete, ktorý je zložený z vecí, a tieto sú nám dané primárne ako prostriedky, nie ako neutrálne objekty. Človek je ten, kto je už vždy určený (bestimmt), naladený, orientovaný podl'a preferencií a odporu. Nie sme jednoducho iba neutrálne prítomní uprostred objektov, ale aktívne situovaní a zaviazaní ku konaniu, ktoré sa istým veciam vyhýba a iné hl'adá. Toto je pre Vattima idea existencie ako „projektu“; iba v rámci horizontu projektu „sú veci dané“. „A práve tu vyvstáva centrálnost' interpretácie: skúsenost' a vedomie pravdy sú artikuláciou projektu, pred-porozumenia toho, čím my, ako existujúce súcna, už vždy sme“ (Vattimo 2016, 33).

Projekt, o ktorom hovorí Heidegger, vníma Vattimo ako analogický ku Kantovým apriórnym formám, ibaže tu sa dôraz kladie na radikálnu konečnost' a dejinnost' ako naše a priori. „Historicko-lingvistický horizont, v ktorom je pre Heideggera rozpustené Kantovo a priori, musí byt' myslený ako dianie. Aj ked' nikdy nevidíme „Zrodenie“ nového sveta, môžeme iba mysliet' bytie týmto spôsobom - ak nechceme upadnút' spät' do objektivistickej metafyziky, ktorá robí našu existenciálnu dejinnost' ne-myslitel'nou“" (Vattimo 2016, 107).

Žijeme svoje bytie ako smrtel'ní vo svete vecí, ktoré sú nám dané v personálnom projekte, ktorým my sami sme. „Realita“ sveta, ktorý sa sám odhalil v autentickom projekte Dasein, je pravdivejšia ako to, čo je zachytené v denných médiách a v neautenticite jalovej reči. Jazyky, ktoré konštituujú epochálny a špeciálny horizont, v ktorom je daná pravda, nie sú mnohopočetné spôsoby alebo pokusy opísat' či „zmerat““ realitu, ale skôr spôsoby, v ktorých sa to „reálne“ stáva pravdivým, prichádzajúc (vstupujúc) do bytia. V jazyku, ktorým hovoríme, je už vždy daný súbor kritérií na odlíšenie pravdy a nepravdy. Skutočnost', že poznanie je artikulácia nášho daného predporozumenia, však neznamená, že nejestvuje diferencia medzi pravdou a omylom, ani neplatí heslo anything goes.

Vattimo si v súvislosti s novými realistickými tendenciami a teóriami kladie viaceré otázky: Potrebuje byt' „realita“ skutočne ochraňovaná niekým a od niečoho? Kto sa obáva interpretácií? Robí si realista starost' o pravdu, alebo o realitu? Máme skutočne jestvujúcna „tam vonku“ pokladat' za fakty, ktoré existujú mimo všetkých interpretácií? A možno to tvrdit' bez toho, aby aj toto tvrdenie nebolo partikulárnou interpretáciou? Kto a prečo cíti potrebu chápat' a obhajovat' pravdu-ako-realitu (truth-as-reality)? Máme reálne akceptovat' prirodzený zákon a l’udskú esenciu? Ako je to $\mathrm{s}$ fundamentmi $\mathrm{v}$ oblasti asistovanej reprodukcie alebo sociálnych práv, ktoré sa týkajú etickej oblasti? Aké sú príčiny „návratu k realite“, zameranému voči postmoderne (Vattimo 2012a, 86)?

Z pohl'adu Vattima fakty nehovoria nič o sebe, no ukázat' na ne prstom je už lingvistický akt. Realizmus sa vždy pokúšal stavat' na „faktoch“, ktoré by mohli byt' 
niečím „tam vonku“, a výpoved’ o nich nezávisí od interpreta. Pravdou je, že noví realisti sú akceptovaní verejnou mienkou ako tí, čo chcú obnovit' „pravé“ hodnoty a sociálnu disciplínu. Ak však nejestvujú fakty, ale len interpretácie, jedinou spoločnou bázou ostávajú interpretácie iných. Nemám síce objektívnu garanciu, ktorou by som presvedčil druhých, môžem však s nimi zdiel'at' niektoré hodnoty, rovnaké skúsenosti či texty, ktoré sme čítali. Podl’a Vattima celé riziko hermeneutiky tkvie v učení, že jediná interpretácia, ktorá je definitívne nesprávna, je tá, ktorá nespoznáva seba ako limitovanú a robí si nárok hovorit' z pohl'adu „Božieho oka“ a odmieta všetky negociácie s presvedčením o jedinej reálnej pravde. Dokonca aj pravda vedeckých propozícií si môže udržat' svoj status iba vtedy, ked' druhý, ktorý zopakoval experiment, prišiel k rovnakému výsledku. Je však toto - pýta sa Vattimo - skutočne miesto (prípad) znovuobjavenia nehybnej bázy a nepreniknutel'nej steny? $?^{3}$

\section{Konfrontácia, poznámky a úvahy}

Zameriam sa d’alej na konfrontáciu a analýzu kl'účových rozdielov Ecovho a Vattimovho myslenia - na chápanie reality a interpretácie. Zohl’adním pritom i niektoré súčasné interpretácie ich diela.

\section{Realita vnútri paradigmy a interpretácií?}

Nosným problémom a bodom sporu oboch autorov je otázka realizmu. Vattimo neodmieta akceptovat' určité bežné, nazvime ich elementárne druhy faktov. Nie je však jasné, kde sa táto akceptácia končí, kde je jej hranica, teda čo spadá do oblasti „elementárnych“, všeobecne prijímaných faktov, a čo do oblasti diferencovaných interpretácií. Podl'a Vattima určit', či je propozícia pravdivá alebo nepravdivá, možno iba vnútri konkrétnej paradigmy. Nejestvuje objektívna korešpondencia, ale paradigmatický horizont, $v$ rámci ktorého je každá korešpondencia verifikovatelná. Vedy sú formy osvetl'ovania reality, pretože ju transformujú bud' do manipulovatel'ných technológií, alebo do univerzálnych formulácií, pričom univerzalita nezávisí od „,prítomnosti“ vecí (being present) (Vattimo, Paterlini 2010, 154). „[...] dokonce i takzvané prísné vědy verifikují a falzifikují své hypotézy jen v rámci jistých paradigmat či předporozumění. Jestli se tedy zdá, že ,fakta‘ nejsou nic jiného než interpretace, prezentuje sa interpretace na druhé straně jako fakt: Hermeneutika není filosofie, nýbrž vyjádření samotné historické existence v období konce metafyziky“ (Rorty, Vattimo 2007, 50).

\footnotetext{
${ }^{3}$ But even the truth of a scientific proposition can keep claiming its status only if others, those who repeat the experiment, come up with the same results. Is this where the immovable base and the impenetrable wall will make their reappearance (Vattimo 2012a, 89)?
} 
U Eca, ako sa môžeme domnievat' a predpokladat', je špecifickým spôsobom prítomná „negatívna teológia“, respektíve jej spôsob myslenia. Ecovu teóriu smieme chápat' v tom zmysle, že realitu nikdy nie sme schopní úplne postihnút', je vždy ,väčšia“" (veritas semper maior), dokážeme však vylúčit' nesprávne výpovede o nej, naša sloboda slova naráža na isté hranice; zároveň sme v niektorých prípadoch schopní aj jednoznačných výpovedí. Ako si všíma talianska teoretička Loredana di Martino, Ecova filozofia konjektúry a falibilizmu ovplyvnená Peirceom sa stala nekompatibilnou s Vattimovou líniou nihilizmu, inšpirovanou Nietzschem a Heideggerom, ked’že vytvoril jemnejšiu líniu slabého postmoderného myslenia. ${ }^{4} \mathrm{~V}$ Ecovom prípade spisovatel'a, nazdáva sa autorka, k nadobudnutiu možných odpovedí vedie kognitívna cesta, ktorá smeruje k uvedomeniu limít interpretácie. Je to cesta podnecujúca čitatela k odmietnutiu zdeformovaných interpretácií reality. Sú momenty, ked' nám svet, ktorý čelí našim interpretáciám, hovorí Nie, a teda sú veci / vety, ktoré nemôžu byt' vypovedané. Spisovatelia neskorého postmodernizmu vytvárajú interpretačný interval, priestor umožňujúci čitatel'om angažovat' sa spolu s autorom v procese skúmania, ktorý síce nemusí viest' ku konečným pravdám, avšak pomôže im obom nadobudnút' lepšie pochopenie reality (Di Martino 2012, 196 - 197, 202 - 203).

Ak si položíme otázku: Čo je pre nás skutočné do tej miery, že zakladá našu väzbu ku skutočnosti vôbec? (Mitterpach 2015, 91 - 101), tak pre Vattima sú touto primárnou skutočnost'ou interpretácie (prítomné a minulé, náboženské, filozofické, vedecké... v rámci určitej paradigmy), pre Eca je to realita, ktorá - hoci interpretovaná, nezávisle od nás (mimo paradigmy a interpretácií) jestvuje a odoláva nesprávnym výkladom. Odkazuje na Searlovo chápanie realizmu, ktorý je založený na presvedčení, že veci „sú“ istým spôsobom, i ked’ možno nikdy nebudeme vediet’ akým. Pritom sme si však istí, že sú práve určitým konkrétnym, a nie iným spôsobom. Vattimo by sa s týmto tvrdením nestotožnil, jeho svet je svetom bez stability. „To znamená, že cokoli přichází do naší zkušenosti, není ničím více ani méně než - interpretací. [...] Svět, jenž nám „zbyl“, je světem navzájem nepřevoditelných, často nesouměřitelných a konfliktních interpretací“ (Hauer 2014, 90).

\section{Vattimovo jenseits von Gut und Böse a Ecovo hl'adanie medzí interpretácie textu}

Ďalším z problémov je tematika limít interpretácie textu. Eco sa zameriaval na štúdium dialektiky medzi právom textov a právom ich interpretov, pričom si uvedomil,

\footnotetext{
${ }^{4}$ Falibilizmu ako epistemickej doktríne, ktorá tvorí základ Peirceovej teórie poznania, sa venujú články Falibilizmus v koncepcii Ch. S. Peircea (Bajúszová 2007) a Abdukcia-súčast' fallibilistickej koncepcie poznania Ch. S. Peirca (Mihina 2000). S odkazom na uvedené články pripomeňme, že z pohl'adu falibilizmu nemôžeme v poznaní dosiahnut' absolútnu presnost', istotu, univerzálnost', a musíme si byt' vedomí omylov v našom poznaní.
} 
že práva interpretov boli nadmerne preceňované a narástol význam postavenia adresáta. Bol presvedčený, že „pojem neomezené semiózy nevede k závěru, že neexistují žádná kritéria interpretace“ (Eco 2009, 12). L. Doležel pripomína, že z Ecovho pohl'adu napísaný text obmedzuje rozsah svojich možných interpretácií. „Meze interpretace existují právě proto, že text nese určitou ,významovou intenci““ (Doležel 2009, 307).

Ako tvrdí M. Fišerová, u Eca sa každý text otvára interpretácii „zmluvne“ určujúcej význam textu, vo výklade významu sa chce pohybovat' v medziach konsenzu, ktorý mu zaručí rozumnost'; dôležité je ustrážit' určitú „rozumnú“ mieru otvorenosti výkladu. Odmieta takú iniciatívu čitatel’a, ktorá text „rozdrobí“, čím stratí svoju vnútornú koherenciu a tvar. Nestotožňuje sa s nekonečným interpretačným driftovaním recipienta diela, s jeho vystavením akýmkolvek interpretáciám, ale skôr s určitou ochranou textu. Snaží sa „dosiahnut' diskurzívne prijatú interpretáciu, ktorá rozpozná význam na základe ,zmluvného realizmu““ (Fišerová 2015, 224; 2009, $454-464)$.

Ako je to v prípade Vattima? Ťažiskom Vattimovej filozofie je interpretácia biblickej zvesti a krest'anského posolstva, ktorému sa venuje vo viacerých svojich prácach. Najvýraznejšie sa tak problematika limít interpretácie textu ukazuje práve tu (aj ked' spornou je aj jeho interpretácia Heideggerovej filozofie a dejín filozofie vôbec, čo je však samostatná téma). V prvom rade musíme zdôraznit', že z pohl’adu talianskeho filozofa príbehy o Ježišovi ako Kristovi boli napísané dodatočne, až po jeho smrti, takže máme dôvody usudzovat', že nejestvujú priame svedecké výpovede a nezachoval sa pre nás žurnalistický záznam vtedajšieho diania. Kanonické evanjeliá sú založené na ústnej tradícii. Rovnako je presvedčený, že verit' v evanjelium v dnešných dňoch a dnešnej epoche znamená najskôr pochopit', že jazyk nedenotuje iba objektívne reality. Evanjelium neodkazuje k externému svetu a nemôže byt' interpretované realisticky (Caputo, Vattimo 2007, 35 - 41).

Na pozadí Ecovho myslenia môžeme konštatovat' a vidiet' - i ked' Eco sám to explicitne neformuluje, nerozvádza a nekonkretizuje svoje hlavné tézy -, že Vattimova interpretácia krest’anského posolstva je jeho „rozdrobením“, „rozbitím“ koherencie, presadením vôle čitatel’a a interpreta. Vattimo sa „vykláňa“z okruhu tých, ktorí prijímajú „pevné“ jadro krest’anstva. Jeho intenciou však nie je otázka korektnej interpretácie Biblie a krest'anstva vôbec, nakol'ko sa nachádza mimo tohto rámca. Explicitne to vyjadril Richard Rorty: „Ptát se, zda tohle je ,legitimní“ či platná verze katolictví či křest’anství, by znamenalo pokládat zcela nesprávnou otázku. Pojem ,legitimity' se nedá aplikovat na to, co Vattimo či kdokoli z nás ve své izolovanosti podniká“ (Rorty, Vattimo 2007, 42). Môžeme tu hovorit’ o Vatti- 
movom jenseit von Gut und Böse - stát' mimo dobrej a zlej, správnej alebo nesprávnej interpretácie, nerozhodovat' o tomto spore, nehl'adat' kritériá pre jednu alebo druhú možnost'. V tomto bode sa s Ecom opät' rozchádza.

\section{Fakt, ktorý nie je faktom}

Ďalším z problémov Vattimovho myslenia, ktorý tu môžeme iba naznačit' a ktorý súvisí s predchádzajúcou tematikou, sa týka chápania faktov v krest’anstve. Vattimo odhliada od reálnosti a „váhy“ faktov v prípade klúčcových obsahov krest'anstva. Krest'anstvo obsahuje silné jadro, ktoré síce možno filozoficky transformovat', no táto transformácia, respektíve transkripcia je deštrukciou pôvodnej zvesti. Krest’anstvo sa zakladá práve na faktoch a na silných obsahoch. Zachovat' určité fundamenty nemusí znamenat' skíznutie do fundamentalizmu a „metafyzickej“ religiozity; je to skôr vernost' a oddanost' pôvodnému, nami nevytvorenému, ale prijatému reálnemu základu (faktu, skutočnosti). V tomto zmysle Heidegger vel'mi správne uviedol - v súvislosti s obsahmi krest’anstva -, že sú prístupné iba prostredníctvom viery. „Ale ukrižovanie a všetko, čo k nemu prináleží, je dejinnou udalost'ou, a táto udalost' ako taká vo svojej špecifickej dejinnosti je dosvedčená iba pre vieru v Písme. O tomto fakte možno,vediet" iba vo viere“ (Heidegger 1988, 317). Heidegger hovorí o fakte, ktorý je sprístupnený vierou. Pokial' teda ide o samo jadro a konkrétne obsahy viery, Vattimo robí skutočne značný krok d’alej ako Heidegger, ktorý si uvedomil špecifický spôsob prístupu k faktom v náboženskej oblasti. Zachoval a nevylúčil takéto fakty prístupné pre vieru a pochopil previazanost' dejinnej udalosti, viery a Písma. Keby sme sa na problém pozreli optikou Umberta Eca, tak práve uvedená trojica je mantinelom, na ktorý nutne narazí množstvo dezinterpretácíi. Vattimo práve túto previazanost' rozbíja.

Ked' Vattimo tvrdí, že krest’anstvo zavádza do sveta princíp interiority, na základe ktorého objektívna realita postupne stráca svoju hlavnú váhu, musíme sa pýtat' $v$ akom zmysle a smere ju stráca? (Rorty, Vattimo 2007, 51). Určite nie v tom zmysle, že je spochybnená či odmietnutá reálnost' faktov a obsahov viery. Pochopitel'ne, Vattimov prístup je možný, zakladá sa ním vlastná podoba viery, jedna z jej možných verzií, avšak súčasne s tým sa vynára problém určenia hraníc toho, čo ešte je, a čo už nie je krest’anské. Americká filozofka Nancy K. Frankenberryová v spomenutej publikácii k Vattimovmu životnému jubileu kladie otázky v podobnom duchu: Ako d’aleko, respektíve do akej miery môže byt' viera zoslabená bez toho, aby stratila celý obsah, celkový zmysel a prestala byt' najzákladnejším propozičným postojom? Jestvuje nejaký bod, v ktorom je krest’anská viera natol'ko zoslabená, že už prestáva byt' rozpoznatel'ná ako krest'anská? (Frankenberry 2007, 273) Možno tvrdit', že Vattimova interpretácia „zoslabila“ a „rozdrobila“ kl'účový text krest’anstva do tej miery, 
že stratil svoju vnútornú koherenciu, tvar a „tvár“ a jeho postoj nadobudol podobu nihilistickej viery.

\section{Záver}

Ako uvádza Santiago Zabala, spoluautor a editor niektorých Vattimových textov, prijat' nestabilný, mnohoznačný a rozdelený stav, ktorý je spojený s naším bytím predurčeným $\mathrm{k}$ diferencii, pominutel'nosti a rozmanitosti, znamená osvojit' si schopnost' aktívne do života zavádzat' a praktizovat' solidaritu, krest’anskú lásku a iróniu.

Podl'a predstavitel'a nového realizmu Maurizia Ferrarisa však irónia - podobne ako smiech - nie je iba nestranná a nenásilná. Špecifická ironická teória slabého myslenia vyjadruje charakteristiky dlhej periódy talianskej filozofie: nedôveru voči vede a technológii, tradicionalizmu a idealizmu. Je to nedôvera voči realizmu a idei progresu vo filozofii (Ferraris 2014, 8 - 9). Ferraris vidí určitú podobnost' svojej a Ecovej realistickej teórie. Spomínaná L. di Martinová si však myslí, že Ecovo postavenie v súčasnom zápase medzi realistami a „slabistami“ (debolisti) nie je také jednoznačné a neproblematické, ako sa nazdáva Ferraris. Na rozdiel od Ferrarisa Eco celkom neodmietal predstavu, že antifundacionalistické myslenie môže byt' silným nástrojom na sociálnu emancipáciu. Namiesto toho, ako sa pokúša autorka ukázat', Eco navrhuje, že v kombinácii s vyšším stupňom realizmu sa slabé myslenie môže stat' myslením slabého v hl'adaní alternatív. Kombinovaním antifundacionalizmu s referenciálnou a politickou agendou Ecovo neskoré dielo vytvára etiku písania, ktoré by malo byt' $\mathrm{v}$ zhode s praxou (jej prispôsobené), čo bolo definované ako neskoro postmoderné impegno. ${ }^{5}$ Spojením postmoderného antifundacionalizmu so sociálnym realizmom nadobúdajú v jeho poslednom období opät’ význam historické fikcie. Vonkajší svet je prenesený do Ecových románov, aby podporoval kognitívnu zmenu prostredníctvom cesty negatívneho realizmu. Jeho ciel'om je rozvíjat' u čitatel'a „negatívnu kapacitu“ odolávat' zlým interpretáciám. Čitatelia sú pozvaní angažovat' sa v akte interpretácie, ktorý bude vytvárat' demokratickú cestu $\mathrm{k}$ dosiahnutiu sociálnej transformácie (Di Martino 2012, 204, 210).

Položme si nakoniec niekol'ko otázok. Nie je istým druhom násilia subjektívne sa zmocnit' reálne daného prostredníctvom nesprávnej interpretácie? Nie je práve objektívne spojené s istou formou slobody, oslobodenia od subjektívneho? Nie je potrebné a dôležité hovorit’ nielen o úlohe a činnosti interpreta, ale aj o „nároku skutočného“" (Anspruch des Wirklichen) či nároku objektu (Anspruch des Objekts), s ktorým je poznávací subjekt konfrontovaný, tak ako sa domnievajú zástancovia transcendentálno-filozofického prístupu (napr. R. Schaeffler, ktorý sa v istých bodoch

\footnotetext{
${ }^{5}$ Impegno - snaha, úsilie, angažovanost'.
} 
prekrýva s Ecom)? Nie sú to práve objekty ako také, ktoré si robia „nárok na smerodajnost" (Maßgeblichkeitsanspruch der Gegenstände), sú určujúce, samostatné, svojbytné, majú prioritu pred nárokom subjektu, ktorý ich nesmie subjektívne deštruovat' a dezinterpretovat'? Nemôžeme vzt'ah subjektu a objektu chápat' ako špecifický spôsob dialogického vzt'ahu, ktorým sa subjekt a objekt navzájom oslobodzujú? Skutočne realita nehovorí sama za seba, úplne mlčí a potrebuje hovorcu? (Schaeffler 2013, 68 - 93)

Ecova a Vattimova teória predstavujú dva spôsoby myslenia s odlišnými východiskami a závermi. V prípade Eca je to dôraz na realitu, stabilitu a hranice $\mathrm{v}$ rámci negatívneho realizmu, respektíve slabej verzie realizmu alebo slabej verzie slabého myslenia (zastávajúcej pozície hypotetizmu a falibilizmu). ${ }^{6} \mathrm{~V}$ prípade Vattima je to dôraz na dianie, interpretáciu a paradigmu v rámci silnej verzie slabého myslenia.

\section{Literatúra}

BAJÚSZOVÁ, Z. (2007): Falibilizmus v koncepcii Ch. S. Peircea. Filozofia, 62 (4), 304 - 309. CAPUTO, J. D., VATTIMO, G. (2007): After the Death of God. New York: Columbia University Press. DI MARTINO, L. (2012): Between "New Realism" and "Weak Thought": Umberto Eco's "Negative Realism" and the Discourse of Late Postmodern Impegno. Quaderni d'italianistica, 33 (2), $189-218$.

DOLEŽEL, L. (2009): Několik poznámek k Ecově sémantice. In: Eco, U.: Meze interpretace. Praha: Karolinum, $302-308$.

ECO, U. (2009): Meze interpretace. Preložil: Ladislav Nagy. Praha: Karolinum.

ECO, U. (2011): Kant a ptakopysk. Preložil: Pavel Štichauer. Praha: Argo.

ECO, U. (2012a): Antiporphyry. In: Vattimo G. - Rovatti P. A. (eds.): Weak Thought. New York: SUNY Press, $75-99$.

ECO, U. (2012b): Od stromu k labyrintu. Preložili: Martin Bažil, Gabriela Chalupská, Zora Obstová, Jiří Pelán, Pavel Štichauer. Praha: Argo.

ECO, U. (2012c): Some remarks on a New Realism. [online], Dostupné na: https://nuovorealismo.files.wordpress.com/2012/12/eco_wcp.pdf (Navštívené: 22. 10. 2020).

ECO, U. (2016): Od hlouposti k šilenství. Zprávy o tekuté společnosti. Preložili: Helena Lergetporer, Gabriela Chalupská, Kateřina Vinšová.Praha: Argo.

FERRARIS, M. (2014): Manifesto of New Realism. Trans. S. De Sanctis. New York: Suny Press

FIŠEROVÁ, M. (2009): Kríza reprezentácie. Filozofia, 64 (5), 454 - 464.

FIŠEROVÁ, M. (2015): Drift dekonštrukcie. Filozofia, 70 (3), 215 - 228.

FRANKENBERRY, N. (2007): Weakening Religious Belief: Vattimo, Rorty and the Holism of the Mental. In: Zabala, S. (ed.): Weakening Philosophy. Essays in Honour of Gianni Vattimo. Montreal - Kingston: McGill-Queen's University Press, 273 - 296.

HAUER, T. (2014): S/krze postmoderni teorie. Praha: Karolinum.

HEIDEGGER, M. (1988): Fenomenológia a teológia. Filozofia, 45 (3), 315 - 326.

\footnotetext{
${ }^{6}$ Nazdávam sa, že Eca môžeme pokladat' za zástancu slabej verzie slabého myslenia, pretože z hl'adiska Peirceovej falibilistickej koncepcie zmyslom l’udského poznania nie je deskripcia vecného sveta.
} 
HEIDEGGER, M. (1996): Byti a čas. Preložili: Ivan Chvatík, Pavel Kouba, Miroslav Petříček, Jiří Němec. Praha: Oikoymenh.

MIHINA, F. (2000): Abdukcia - súčast' fallibilistickej koncepcie poznania Ch. S. Peirca. Filozofia, 55 (10), $764-776$.

MITTERPACH, K. (2015): Prečo sa Heidegger pýtal na bytie? Philosophica Critica, 1 (1), 91 101. DOI: 10.17846/PC.2019.1.1.91-101

RORTY, R., VATTIMO, G. (2007): Budoucnost náboženství. Praha: Nakladatelství Karolinum.

SCHAEFFLER, R. (2013): ,Freiheit, die frei macht ${ }^{\star}$ - Zur Weiterentwicklung eines transzendentalen Gottesbegriffs. In: Irlenborn, B. -Tapp, Ch. (eds.): Gott und Vernunft: Neue Perspektiven zur Transzendentalphilosophie Richard Schaefflers. Freiburg - München: Verlag Karl Alber, $68-93$.

ŠTÚR, M. (2018): Metafora ako kritérium posunov v chápaní jazyka a komunikácie. World Literature Studies, 10 (3), $68-85$.

VATTIMO, G. (2003): Abschied. Theologie, Metaphysik und die Philosophie heute. Wien: Verlag Turia + Kant.

VATTIMO, G., PATERLINI, P. (2010): Not Being God. A Collaborative Autobiography. New York: Columbia University Press.

VATTIMO, G. (2012a): Realism in two pieces. Phainomena. Selected Essays in Contemporary Italian Philosophy, 21 (82 - 83), $85-89$.

VATTIMO, G., ROVATTI, P. A. (2012b): Weak Thought. New York: Suny Press.

VATTIMO, G. (2016): Of Reality. The Purposes of Philosophy. New York: Columbia University Press.

Martin Vašek

Univerzita Konštantína Filozofa v Nitre

Filozofická fakulta

Katedra filozofie

Hodžova 1

94974 Nitra

Slovenská republika

e-mail: mvasek@ukf.sk

ORCID ID: https://orcid.org/0000-0001-7326-0047 